\title{
Chemical and Immunological Characterization of a Novel Amphipathic Antigen from Biotype B Streptococcus sanguis
}

\author{
By TOSHIKO YAMAMOTO, ${ }^{1}$ TOSHIHIKO KOGA, ${ }^{1}$ JUNN MIZUNO ${ }^{2}$ \\ AND SHIGEYUKI HAMADA ${ }^{1}$ * \\ ${ }^{1}$ Department of Dental Research, National Institute of Health, 2-10-35 Kamiosaki, \\ Shinagawa-ku, Tokyo 141, Japan \\ ${ }^{2}$ Department of Preventive Dentistry, Kagoshima University Dental School, \\ Kagoshima 890, Japan
}

(Received 31 October 1984 ; revised 29 January 1985)

\begin{abstract}
A new type of amphipathic antigen was extracted from whole cells of Streptococcus sanguis ATCC 10557 (biotype B, serotype II) by the phenol/water method. The extract was treated with nuclease $P_{1}$, and was applied to a column of Sepharose 6B. Each fraction was checked by passive haemagglutination (PHA) and immunodiffusion tests against anti-10557 serum which was obtained by immunizing rabbits with whole cells of strain ATCC 10557. Strong PHA activity was demonstrated in the first hexose-containing peak (peak 1) eluted near the void volume, while the second hexose-containing peak (peak 2) produced a heavy band against anti10557 serum in an immunodiffusion test. The third peak (peak 3) which partially overlapped with peak 2 reacted with concanavalin $A$, but not with the antiserum, in agar gel. Peaks 2 and 3 had no PHA activity. Peak 1 contained only $1 \%$ phosphorus, indicating that cells of strain ATCC 10557 possess an amphipathic antigen which differs from the lipoteichoic acids that are common in many Gram-positive bacteria. Peak 1 was a fatty acid-substituted heteropoiysaccharide composed of glucose, galactose, mannose, glycerol and fatty acids in a molar ratio of approximately $1 \cdot 0: 1 \cdot 3: 2 \cdot 7: 0 \cdot 3: 1 \cdot 0$. PHA activity was inhibited in the presence of polymerized mannose. Peak 2 was composed of glucose, galactose, rhamnose and $\mathrm{N}$-acetylgalactosamine in a molar ratio of approximately $1 \cdot 0: 1 \cdot 4: 0 \cdot 8: 0 \cdot 8$, which was essentially identical to the serotype II carbohydrate antigen reported previously.
\end{abstract}

\section{INTRODUCTION}

Lipoteichoic acids (LTAs) occur as a uniform class of polymers in most species of Grampositive bacteria (Wicken \& Knox, 1980; Fischer et al., 1978). LTAs are a group of amphipathic polymers composed of glycolipids, alanine and a polyglycerophosphate (PGP) backbone. They are implicated in the regulation of autolysin action (Tomasz, 1974), the adherence of organisms such as streptococci and staphylococci to mammalian cell surfaces (Ofek et al., 1975), and the control of $\mathrm{Mg}^{2+}$ supply to the cell membrane (Hughes et al., 1973). McCarty (1959) reported that certain bacterial species such as micrococci and streptococci lacked this type of polymer.

Extensive investigations have reported that Micrococcus species contain an antigenic substance composed of $\alpha$-linked branched mannan linked glycosidically to a diglyceride of the cell membrane (Owen \& Salton, 1975; Pless et al., 1975; Powell et al., 1975). This type of lipomannan has been suspected as serving the same function as LTAs (Lambert et al., 1977). On the other hand, Wicken et al. (1978) described a fatty acid-substituted heteropolysaccharide from Actinomyces viscosus (AcA) as another amphipathic antigen, which might be unique to

Abbreviations: Con A, concanavalin A; LTA, lipoteichoic acid; PGP, polyglycerophosphate; PHA, passive haemagglutination; n-PWE, nuclease-treated phenol/water extract; SRBC, sheep red blood cells. 
Actinomyces. Furthermore, Rosan (1978) showed that most strains designated Streptococcus mitis (mitior) lacked LTAs, confirming the earlier finding of McCarty (1959) that more than $50 \%$ of Streptococcus viridans and Streptococcus sanguis did not possess PGP antigen. We have also found that 47 strains of biotype B $S$. sanguis lacked LTAs (Hamada et al., 1980a). Subsequent study by passive haemagglutination (PHA) test revealed that several strains of biotype B $S$. sanguis possessed a unique amphipathic antigen (Mizuno et al., 1983). The present paper reports the chemical and immunological properties of this unique antigen.

\section{METHODS}

Micro-organisms. Streptococcus sanguis ATCC 10557 (biotype B, serotype II; Hamada et al., 1980b) was used in this study. For preparation of antigens, organisms were grown at $37^{\circ} \mathrm{C}$ for $20 \mathrm{~h}$ in $401 \mathrm{TTY}$ broth (Hamada \& Torii, 1978). Cells were harvested by centrifugation, washed three times with distilled water and freeze dried $(40 \mathrm{~g}$ dry weight). S. sanguis ATCC 10556 (biotype A, serotype I; Hamada et al., 1980b), Streptococcus pyogenes Sv (group A, M type 3 = ATCC 21059), Micrococcus luteus ATCC 4698 and Actinomyces viscosus Nyl were also cultivated similarly to prepare amphipathic antigens for comparison with that of $S$. sanguis ATCC 10557.

Reagents. All the chemicals used were of analytical grade and were purchased from commercial sources. Nuclease $\mathbf{P}_{1}$ from Penicillium citrinum [nucleate 5'-nucleotidohydrolase (3'-phosphohydrolase); EC 3.1.3.1.; Fujimoto et al., 1974] was obtained from Yamasa Shoyu Co., Choshi, Japan. Sepharose 6B and Blue Dextran were from Pharmacia. Concanavalin A (Con A, grade III) and mannan from bakers' yeast were obtained from Sigma. Authentic standards of fatty acid methyl esters were products of Applied Science Laboratories, State College, PA, USA, and eicosanoic acid was kindly supplied by A. F. Moribayashi, National Institute of Health, Tokyo, Japan.

Antisera. Rabbit antisera specific for PGP and whole cells of strain ATCC 10557 were the same lots that were previously used (Koga et al., 1983; Mizuno et al., 1983).

Immunological methods. PHA tests were done with sensitized sheep red blood cells (SRBC) according to the description of Hewett et al. (1970), as modified by Hamada et al. (1979). Hapten inhibition of PHA was achieved as follows. Hapten $(0$ to $0.8 \mathrm{M}$ in $20 \mu \mathrm{l})$ was mixed with an equal volume of anti-10557 serum $(1: 200$ dilution), and incubated at $37{ }^{\circ} \mathrm{C}$ for $30 \mathrm{~min}$, followed by addition of $2 \%(\mathrm{v} / \mathrm{v}) \mathrm{SRBC}(40 \mu \mathrm{l})$ sensitized with amphipathic antigen $\left(5 \mu \mathrm{g} \mathrm{ml}^{-1}\right)$. The immunodiffusion test was done in $1.5 \%(\mathrm{w} / \mathrm{v})$ agar (Difco) gel in saline as described previously (Hamada et al., 1979). In some experiments, Con A $\left(5 \mathrm{mg} \mathrm{ml}^{-1}\right)$ was used for immunodiffusion.

Extraction of antigens and lipids from bacterial cells. Antigens were extracted by the method of Moskowitz (1966) with slight moditication (Mizuno et al., 1983) from whole cells of $S$. sanguis ATCC 10557 (37 g dry weight). After cells were suspended in water at a concentration of $10 \mathrm{mg} \mathrm{ml}^{-1}$, an equal volume of $95 \%(\mathrm{v} / \mathrm{v})$ aqueous phenol was added. The mixture was gently shaken at room temperature for $1 \mathrm{~h}$, centrifuged at $5000 \mathrm{~g}$ for $20 \mathrm{~min}$, and the upper aqueous layer was pipetted out. An equal volume of water was added to the phenol layer and the extraction procedure was repeated. The aqueous layer was removed and combined with that of the first extraction. To remove phenol, the extract was dialysed overnight against running tap water at room temperature and then against 10 vols distilled water for $8 \mathrm{~h}$ at $4{ }^{\circ} \mathrm{C}$. The dialysate was centrifuged for $20 \mathrm{~min}$ at $8000 \mathrm{~g}$ to remove insoluble material, concentrated by rotary evaporation and then freeze dried $(1.39 \mathrm{~g})$. The extract $(1.35 \mathrm{~g})$ was dissolved in $90 \mathrm{ml}$ Tris $/ \mathrm{HCl}$ buffer $(0.01 \mathrm{M}, \mathrm{pH} 7.5)$ containing $0.1 \mathrm{~mm}-\mathrm{MgCl}_{2}$ and nuclease $\mathrm{P}_{1}(10 \mathrm{mg})$, and was incubated at $37^{\circ} \mathrm{C}$ for $24 \mathrm{~h}$. The reaction mixture was then dialysed further against distilled water (1 litre; five times) at $4{ }^{\circ} \mathrm{C}$ for $8 \mathrm{~h}$ and freeze dried to yield nuclease-treated phenol/water extract (n-PWE, $216 \mathrm{mg}$ ). For comparison, amphipathic antigens were extracted and partially purified in the same manner from $S$. sanguis ATCC 10556 and $S$. pyogenes Sv (LTAs), M. luteus ATCC 4698 (lipomannan) and $A$. viscosus Nyl (AcA) as described above. Cellular lipids were extracted by the method of Bligh \& Dyer (1959).

Purification of crude extract. The n-PWE ( $200 \mathrm{mg}$ ) was dissolved in $10 \mathrm{ml}$ ammonium acetate $(0 \cdot 2 \mathrm{M}, \mathrm{pH} 7 \cdot 0)$. Insoluble material was removed by centrifugation $(5000 \mathrm{~g}, 10 \mathrm{~min})$ and the supernatant was applied to a column $(2.5 \times 55 \mathrm{~cm})$ of Sepharose 6B that had been equilibrated with $0.2 \mathrm{M}$-ammonium acetate, $\mathrm{pH} 7 \cdot 0$. The elution was done with the same buffer by downward flow at a rate of $20 \mathrm{ml} \mathrm{h}^{-1}$. Fractions $(3.0 \mathrm{ml}$ per tube) were collected and assayed for phosphorus, total hexose and ribose contents and immunological activities.

Colorimetric analyses. Protein was measured by the Lowry method using bovine serum albumin as a standard. Total phosphorus was determined by the method of Lowry et al. (1954). Ester groups in lipids were determined by the method of Snyder \& Stephens (1959). Total hexose was determined by the anthrone $/ \mathrm{H}_{2} \mathrm{SO}_{4}$ method using glucose as a standard (Scott \& Melvin, 1953). Ribose was estimated by the orcinol/HCl method (Mejbaum, 1939). Hexosamine was quantified by the method of Dische \& Shettles (1948). Sialic acids were determined by the thiobarbituric acid method (Aminoff, 1961). For quantitative analysis of amino acids and amino sugars, samples were hydrolysed in $6 \mathrm{M}-\mathrm{HCl}$ in vacuum-sealed tubes at $100^{\circ} \mathrm{C}$ for $14 \mathrm{~h}$ and analysed with a Hitachi amino acid analyser (model 835; Hitachi, Tokyo, Japan). 
Sugar analyses. Individual sugars were identified and estimated by GC using a Shimadzu GC-7AG gas chromatograph fitted with a flame ionization detector. $\mathrm{N}_{2}$ was used as a carrier gas at a flow rate of $50 \mathrm{ml} \mathrm{min}^{-1}$. Neutral sugars, amino sugars and glycerol were identified as trimethylsilyl derivatives (Sweeley et al., 1963) and alditol acetate derivatives (Sawardeker et al., 1965; Niedermeier, 1971) after samples (1 mg) had been hydrolysed in $2 \mathrm{M}-\mathrm{HCl}(1 \mathrm{ml})$ for $2 \mathrm{~h}$ at $100{ }^{\circ} \mathrm{C}$. The trimethylsilyl derivatives were chromatographed on a glass column ( $3 \mathrm{~mm} \times 2.6 \mathrm{~m}$ ) of $10 \%$ silicone GE SE-30 on Chromosorb W (60 to 80 mesh; Wako Pure Chemical Industries, Osaka, Japan). The column temperature was programmed for $150{ }^{\circ} \mathrm{C}$ to $200{ }^{\circ} \mathrm{C}$ at increments of $3{ }^{\circ} \mathrm{C} \mathrm{min}{ }^{-1}$. The alditol acetate derivatives were chromatographed on a glass column $(3 \mathrm{~mm} \times 2 \cdot 1 \mathrm{~m})$ of $3 \%$ ECNSS-M on gaschrom Q (100 to 120 mesh; Wako). The column temperature was programmed for $150{ }^{\circ} \mathrm{C}$ to $200{ }^{\circ} \mathrm{C}$ at increments of $3{ }^{\circ} \mathrm{C} \mathrm{min}-1$ after $4 \mathrm{~min}$ of running at $150^{\circ} \mathrm{C}$.

Fatty acid analyses. Fatty acids were identified as their methyl esters by GC. These were prepared by heating samples with $4 \mathrm{ml}$ methanolic $5 \% \mathrm{HCl}$ at $105^{\circ} \mathrm{C}$ for $3 \mathrm{~h}$ in sealed tubes. The esters were chromatographed on glass columns $(3 \mathrm{~mm} \times 2.1 \mathrm{~m}$ ) of $25 \%$ diethylene glycol succinate on Chromosorb W (60 to $80 \mathrm{mesh}$; Wako) and $1.5 \%$ silicone GE SE-30 on Chromosorb W (60 to 80 mesh; Wako) at $170^{\circ} \mathrm{C}$. For internal standard, eicosanoic acid was added to samples before methanolysis.

Acyl residues. Acyl residues of short to medium chain length were identified as methyl esters by GC after samples had been treated by acid hydrolysis followed by methylation (T. Yamamoto, T. Koga, \& S. Hamada, unpublished observations). After hydrolysis $\left(2 \mathrm{M}-\mathrm{HCl}, 100^{\circ} \mathrm{C}, 2 \mathrm{~h}\right)$, fatty acids in the antigen hydrolysate were extracted into chloroform, and the acidic aqueous solution was evaporated by flushing with $\mathrm{N}_{2}$. Methanol (one drop) and a solution of diazomethane in diethyl ether $(3 \mathrm{ml})$ were added to the residue, and the tube was sealed and incubated for $30 \mathrm{~min}$ at $25^{\circ} \mathrm{C}$. The diethyl ether and excess diazomethane were removed under a gentle stream of $\mathrm{N}_{2}$. The resulting methyl esters were extracted into acetone and chromatographed on a column $(3 \mathrm{~mm} \times 2 \cdot 1 \mathrm{~m})$ of $10 \%$ silicone GE SE-30 on Chromosorb W (60 to 80 mesh; Wako). The column temperature was programmed for $80{ }^{\circ} \mathrm{C}$ to $200{ }^{\circ} \mathrm{C}$ at increments of $2{ }^{\circ} \mathrm{C} \mathrm{min}^{-1}$.

\section{RESULTS}

Purification of the nuclease-treated phenol/water extract of S. sanguis ATCC 10557

Fractionation of the n-PWE by Sepharose 6B column chromatography gave four hexose peaks (P1, P2, P3 and P4; Fig. 1). None of these reacted with anti-PGP serum by immunodiffusion (Fig. $2 a$ ) or in the PHA test (data not shown). A major peak of n-PWE of $S$. sanguis ATCC 10556 was composed of a large amount of phosphorus and hexose, giving a strong PHA reaction and a precipitin band with anti-PGP serum (Fig. 2a). P1 of the n-PWE of $S$. sanguis ATCC 10557 sensitized SRBC to give a positive PHA reaction upon addition of anti10557 serum, but it did not produce any precipitin band against anti-10557 serum in the immunodiffusion test (Figs 1 and $2 b$ ). On the other hand, $\mathrm{P} 2$ gave a single precipitin band against anti-10557 serum (Fig. $2 b$ ), which fused with the precipitin line formed between anti10557 serum and $S$. sanguis serotype II polysaccharide antigen (Koga et al., 1983) or the hot saline extract of cells of strain ATCC 10557 in the immunodiffusion test. However, this second peak lacked the ability to sensitize SRBC. Peaks 1 and 3 also gave a precipitin line in gel diffusion against Con A (Fig. 3), indicating the presence of a sugar polymer in these fractions. In this regard yeast mannan and $M$. luteus lipomannan also gave a fused precipitin band against Con A. P4 reacted with neither anti-10557 serum nor Con A, although it contained a large amount of hexose. The yields (mg dry weight) of P1 (fraction numbers 37 to 47 of Fig. 1), P2 (fractions 61 to 67), P3 (fractions 71 to 75 ) and P4 (fractions 76 to 86 ) from the n-PWE (200 mg) of $S$. sanguis ATCC 10557 were $14 \cdot 2,11 \cdot 6,8 \cdot 0$ and $35 \cdot 2$, respectively.

\section{Chemical compositions}

The chemical compositions of peaks 1 and 2, isolated from the n-PWE of $S$. sanguis ATCC 10557 by Sepharose 6B chromatography, were determined colorimetrically (Table 1). P1 contained glucose, galactose and mannose in a molar ratio of $1 \cdot 0: 1 \cdot 3: 2 \cdot 7$. In addition, small amounts of rhamnose, galactosamine and glycerol were found, but their molar ratios to glucose were less than 0.4 (Table 1). It was noted that P1 contained fatty acids which accounted for $15 \%$ of the dry weight, whereas other peaks contained no detectable fatty acids. The major fatty acids found in $\mathrm{P} 1$ and cellular lipids were $\mathrm{C}_{16: 0}, \mathrm{C}_{18: 1}, \mathrm{C}_{16: 1}$ and $\mathrm{C}_{18: 0}$, and the overall distribution in the two fractions was similar (Table 2). Short chain acyl residues such as succinic acid, or sialic 

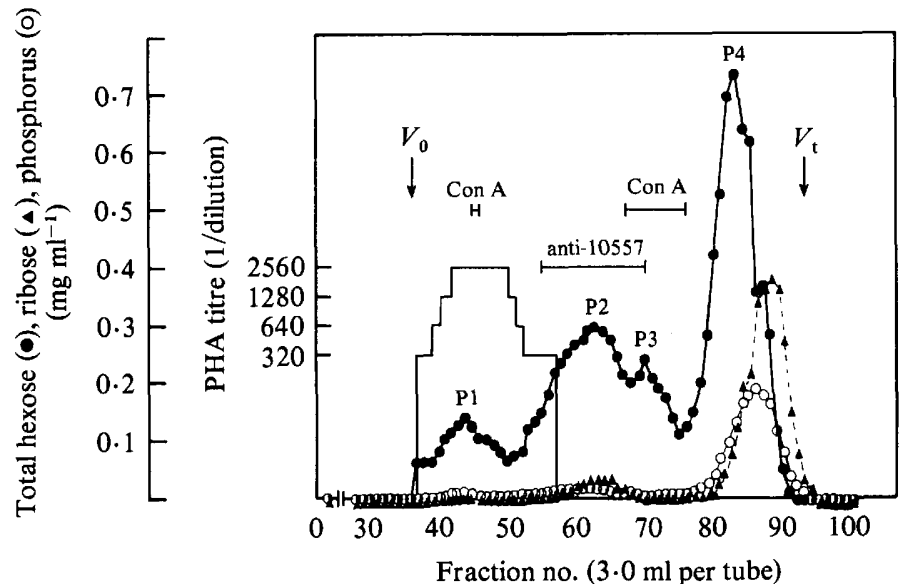

Fig. 1. Gel filtration chromatography of nuclease-treated phenol/water extract (n-PWE) of $S$. sanguis ATCC 10557 on Sepharose 6B. The n-PWE $(200 \mathrm{mg})$ was applied to a Sepharose 6B column $(2.5 \times 55 \mathrm{~cm})$ and eluted with $0.2 \mathrm{M}$-ammonium acetate $(\mathrm{pH} 7.0)$. Total hexose $(O)$, phosphorus $(O)$ and ribose $(\boldsymbol{A})$ were determined in each fraction. The bars indicate the range where the fraction gave a precipitin line against anti-10557 serum or Con $\mathrm{A}$ by diffusion tests in agar gel; $V_{0}$, void volume; $V_{\mathrm{t}}$, total bed volume.
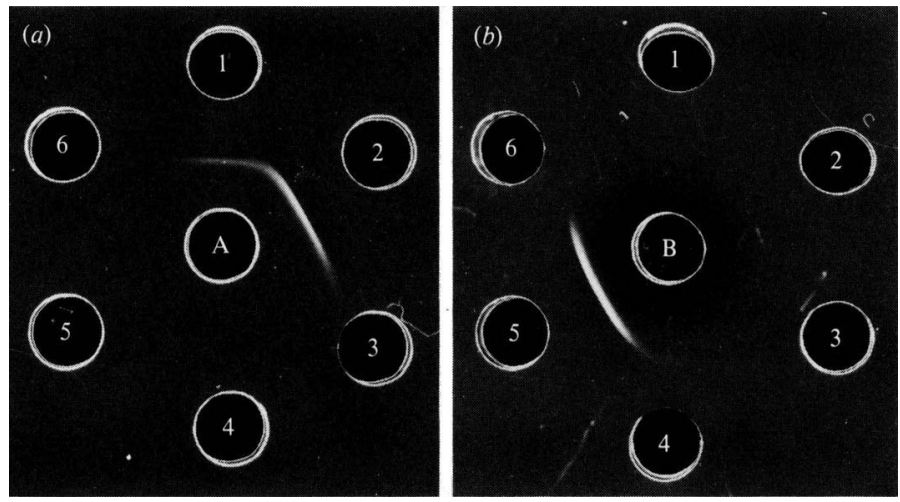

Fig. 2. Immunodiffusion of lipoteichoic acids (LTAs) and peak fractions of $S$. sanguis ATCC 10557. Wells: 1, LTA of $S$. sanguis ATCC 10556; 2, LTA of $S$. pyogenes Sv; 3, P4 of strain ATCC 10557; 4, P3 of strain ATCC 10557; 5, P2 of strain ATCC 10557; 6, P1 of strain ATCC 10557; A, anti-PGP serum; B, anti-10557 serum.

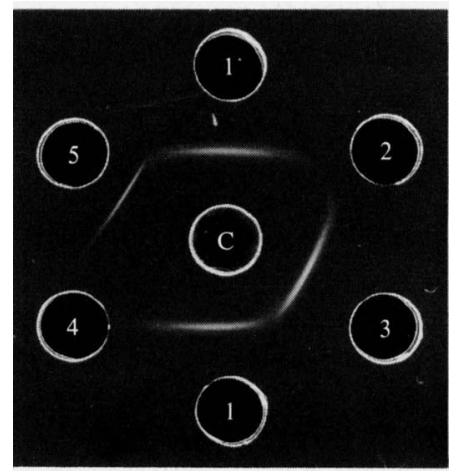

Fig. 3. Gel diffusion of mannan, lipomannan and peak fractions of $S$. sanguis ATCC 10557 against Con A. Wells: 1, mannan $\left(1 \mathrm{mg} \mathrm{m}^{-1}\right) ; 2$, P1 of strain ATCC $10557\left(2 \mathrm{mg} \mathrm{m}^{-1}\right) ; 3$, P3 of strain ATCC $10557\left(2 \mathrm{mg} \mathrm{ml}^{-1}\right) ; 4, \mathrm{P} 2$ of strain ATCC $10557\left(2 \mathrm{mg} \mathrm{m}^{-1}\right) ; 5$, lipomannan of $M$. luteus ATCC $4698\left(2 \mathrm{mg} \mathrm{ml}^{-1}\right)$; C, Con A (suspension of $5 \mathrm{mg} \mathrm{ml}^{-1}$ ). 
Table 1. Chemical composition of peak fractions of nuclease-treated phenol/water extracts of S. sanguis ATCC 10557

Quantitative analyses were done by colorimetric methods after determination of sugar components by $\mathrm{GC}$.

\begin{tabular}{lrcrc}
\multicolumn{1}{c}{ Component } & $\overbrace{\begin{array}{c}\text { Amount } \\
\left(\mu \mathrm{g} \mathrm{mg}^{-1}\right)\end{array}}^{\text {Peak 1 }}$ & $\begin{array}{c}\text { Molar } \\
\text { ratio }\end{array}$ & $\begin{array}{c}\text { Amount } \\
\left(\mu \mathrm{g} \mathrm{mg}^{-1}\right)\end{array}$ & $\begin{array}{c}\text { Molar } \\
\text { ratio }\end{array}$ \\
Glucose & 100 & $1 \cdot 0$ & 232 & $1 \cdot 0$ \\
Galactose & 128 & $1 \cdot 3$ & 322 & $1 \cdot 4$ \\
Mannose & 274 & $2 \cdot 7$ & 23 & $0 \cdot 1$ \\
Rhamnose & 38 & $0 \cdot 4$ & 163 & $0 \cdot 8$ \\
Galactosamine & 28 & $0 \cdot 3$ & 183 & $0 \cdot 8$ \\
Glycerol & 13 & $0 \cdot 3$ & 0 & 0 \\
Phosphorus & 17 & $1 \cdot 0$ & 30 & $0 \cdot 8$ \\
Fatty acids* & 153 & $1 \cdot 0$ & 0 & 0 \\
Peptide & 46 & - & 48 & - \\
Succinic acid & 0 & 0 & ND & - \\
Sialic acid & 0 & 0 & ND & - \\
& ND, Not done. & & \\
& * Calculated as C & &
\end{tabular}

Table 2. Fatty acid composition of cellular lipids and amphipathic antigen of S. sanguis ATCC 10557

$\begin{array}{ccc}\text { Fatty acid } & \overbrace{\text { Cellular lipids }}^{\text {Percentage in: }} \\ \mathrm{C}_{12: 0} & 2 \cdot 3 & 0 \cdot 7 \\ \mathrm{C}_{14: 0} & 6 \cdot 1 & 5 \cdot 9 \\ \mathrm{C}_{14: 1} & 1 \cdot 1 & - \\ \mathrm{C}_{16: 0} & 32 \cdot 5 & 38 \cdot 2 \\ \mathrm{C}_{16: 1} & 15 \cdot 1 & 14 \cdot 8 \\ \mathrm{C}_{18: 0} & 8 \cdot 0 & 8 \cdot 7 \\ \mathrm{C}_{18: 1} & 33 \cdot 6 & 31 \cdot 7\end{array}$

acid were not detected in P1. P2 was composed of glucose, galactose, rhamnose and galactosamine in a molar ratio of $1 \cdot 0: 1 \cdot 4: 0 \cdot 8: 0 \cdot 8$ (Table 1). P3 was composed of peptide and sugars. The component sugars were glucose, galactose, mannose, rhamnose and galactosamine (data not shown). The presence of mannose in P1 and P3 should account for the reactivity of these preparations with Con A in the gel diffusion tests (Figs 1 and 3). P4 was a major carbohydrate peak which was composed of only glucose. The major fatty acids found in LTA and cellular lipid from $S$. sanguis ATCC 10556 were $C_{16: 0}, C_{18: 0}$ and $C_{18: 1}$ together with smaller amounts of $\mathrm{C}_{16: 1}$. The fatty acids in $\mathrm{P} 1$ should play an important role in the spontaneous sensitization of SRBC, which resulted in macroscopic haemagglutination upon addition of anti10557 serum to P1. Inhibition studies of PHA using P1-sensitized SRBC indicated that P3 strongly inhibited the PHA reaction at a concentration of $0.5 \mathrm{mg} \mathrm{ml}^{-1}$. Yeast mannan caused inhibition at $3.6 \mathrm{mg} \mathrm{ml}^{-1}$; other compounds including neutral and amino sugars and glycerol phosphates did not show any inhibition at concentrations as high as $50 \mathrm{mg} \mathrm{ml}^{-1}$ or $800 \mu \mathrm{mol} \mathrm{ml}^{-1}$ (data not shown).

\section{DISCUSSION}

The pioneering study of McCarty (1959) demonstrated that not all Gram-positive bacteria contain PGP: 16 of 32 strains of $S$. viridans (many of them are now classified as $S$. mitior) and group H Streptococcus lacked PGP. It should be noted that group H streptococci and $S$. sanguis 
are closely related. Indeed, some investigators claimed that they are synonymous (Cole et al., 1976; Rosan et al., 1976; Facklam, 1977). The lipoheterosaccharide (P1) of S. sanguis ATCC 10557 reported here adds another category of polymers, that possess both hydrophobic and hydrophilic properties, to the cellular components of Gram-positive bacteria, although recovery of the purified amphiphile was extremely low $(0.04 \%$ of the starting dry cell weight). The major portion of this amphiphile (P1) was composed of a heterosaccharide of mannose, galactose, glucose and glycerol in the approximate molar ratio of $2 \cdot 7: 1 \cdot 3: 1 \cdot 0: 0 \cdot 3$. Very low contents of phosphorus and glycerol indicate that the composition of P1 is quite different from the LTA of $S$. sanguis ATCC 10556. The latter LTA contained phosphorus, glycerol and glucose in the molar ratio of $1 \cdot 0: 0 \cdot 9: 0 \cdot 8$, but no galactose, mannose or rhamnose was detected.

Several amphipathic antigens have been isolated from bacteria including lipopolysaccharides and lipoproteins in Gram-negative bacteria, LTAs in most Gram-positive bacteria (Wicken \& Knox, 1980), succinyl lipomannan in Micrococcus species (Salton, 1983), Forssman antigen in Streptococcus pneumoniae (Holtje \& Tomasz, 1975) and fatty acid-substituted heteropolysaccharide (AcA) in Actinomyces viscosus (Wicken et al., 1978). Although AcA contains sugars that are similar to streptococcal amphiphile P1, we could not find immunological cross-reaction between AcA and Pl by the PHA reaction. Furthermore, P1 did not contain succinyl residues, although both P1 and lipomannan of Micrococcus species (Owen \& Salton, 1975) reacted with Con A (Fig. 3). In addition, Jones et al. (1983) have recently reported a new type of amphiphile from $A$. viscosus T14V and T14AV which contained sialic acid and reacted with Con A. However, sialic acid could not be detected in P1. The amphipathic nature of P1, which was confirmed by its haemagglutinating ability, should be ascribed to the fatty acids like LTAs in other streptococcal species. The percentage of the major fatty acids $\left(C_{16: 0}, C_{16: 1}, C_{18: 0}\right.$ and $\mathrm{C}_{18: 1}$ ) of P1 was similar to that of the cellular lipids and LTAs of most oral and group A streptococci (Chiu et al., 1974; Ofek et al., 1975; Lambert \& Moss, 1976; Rudczynski \& Jackson, 1978).

Attention must be paid to the report by Hogg \& Embery (1982), which demonstrated that both $S$. sanguis NCTC 7864 (this strain corresponds to S. sanguis ATCC 10557) and S. sanguis NCTC 7863 (synonymous with strain ATCC 10556) possessed LTAs. Our systemic survey on the distribution of LTAs showed that all biotype B strains of $S$. sanguis including strain ATCC 10557 lacked LTA (Hamada et al., 1980 a; Mizuno et al., 1983). Rosan (1978) also did not find glycerol teichoic acids in this strain. We feel that the NCTC 7864 strain used by Hogg \& Embery (1982) must be rechecked in terms of its physiological properties.

The role of the amphipathic antigen of biotype B S. sanguis remains to be elucidated. Since many biotype B $S$. sanguis have been isolated from the human mouth as well as blood of patients with subacute bacterial endocarditis (White \& Niven, 1946), this amphiphile, like LTA (Beachey \& Ofek, 1976), may participate in the adherence to various host cell surfaces. Our preliminary experiment has shown that $\mathrm{P} 1$ possessed strong B cell mitogenic activity and was a polyclonal B cell activator. The immunological activity of $\mathrm{Pl}$ will be reported elsewhere in detail.

It is of interest to note that P2 and P4 were essentially similar to serotype II antigen and a major carbohydrate substance reported by Koga et al. (1983), respectively. Serotype II antigen and the major carbohydrate peak substance were extracted from purified cell walls with cold trichloroacetic acid. These findings indicate that phenol/water extraction does remove a major component polysaccharide of the cell wall, although the method is known to be mild (Moskowitz, 1966). P3 reacted with Con $\mathrm{A}$ as did $\mathrm{P} 1$, but $\mathrm{P} 3$ did not contain detectable fatty acids, suggesting that $\mathrm{P} 3$ might be a deacylated product of $\mathrm{P} 1$. This idea was supported by the finding that P3 was a strong inhibitor of the PHA reaction between P1-sensitized SRBC and anti-10557 serum.

\section{REFERENCES}

AminofF, D. (1961). Methods for the quantitative estimation of $N$-acetylneuraminic acid and their application to hydrolysates of sialomucoids. Biochemical Journal 81, 384-392.
BEACHEY, E. H. \& OFEK, I. (1976). Epithelial cell binding by group A streptococci by lipoteichoic acid on fimbriae denuded of $\mathrm{M}$ protein. Journal of Experimental Medicine 143, 759-771. 
Bligh, E. G. \& Dyer, W. J. (1959). A rapid method of total lipid extraction and purification. Canadian Journal of Biochemistry and Physiology 37, 911-917.

Chiu, T. H., Emdur, L. I. \& Platt, D. (1974). Lipoteichoic acids from Streptococcus sanguis. Journal of Bacteriology 118, 471-479.

Cole, R. M., Calandra, G. B., Huff, E. \& Nugent, K. M. (1976). Attributes of potential utility in differentiating among 'group $\mathrm{H}$ ' streptococci or Streptococcus sanguis. Journal of Dental Research 55 , A142-A153.

Dische, Z. \& Shettles, L. B. (1948). A specific color reaction of methylpentose and a spectrophotometric micromethod for their determination. Journal of Biological Chemistry 175, 595-603.

FaCklaM, R. R. (1977). Physiological differentiation of viridans streptococci. Journal of Clinical Microbiology 5, 184-201.

Fischer, W., Nakano, M., Laine, R. A. \& Bohrer, W. (1978). On the relationship between glycerophosphoglycolipids and lipoteichoic acids in grampositive bacteria. I. The occurrence of phosphoglycolipids. Biochimica et biophysica acta 528, 288-297.

Fujimoto, M., Kuninaka, A. \& Yoshino, H. (1974). Purification of a nuclease from Penicillium citrinum. Agricultural and Biological Chemistry 38, 777-783.

Hamada, S. \& ToRII, M. (1978). Effect of sucrose in culture media on the location of glucosyltransferase of Streptococcus mutans and cell adherence to glass surfaces. Infection and Immunity 20, 592-599.

Hamada, S., Mizuno, J. \& Kotani, S. (1979). Serological properties of cellular and extracellular glycerol teichoic acid antigens of Streptococcus mutans. Microbios 25, 155-166.

Hamada, S., Mizuno, J., Kotani, S. \& Toril, M. $(1980 a)$. Distribution of lipoteichoic acids and other amphipathic antigens in oral streptococci. FEMS Microbiology Letters 8, 93-96.

Hamada, S., Tori, M., Tsuchitani, Y. \& Kotani, S. $(1980 \mathrm{~b})$. Isolation and immunobiological classification of Streptococcus sanguis from human tooth surface. Journal of Clinical Microbiology 156, 809817.

Hewett, M. J., Knox, K. W. \& Wicken, A. J. (1970). Studies on the group $F$ antigen of lactobacilli: detection of antibodies by haemagglutination. Journal of General Microbiology 60, 315-322.

HoGG, S. D. \& EMBERY, G. (1982). Blood-groupreactive glycoprotein from human saliva interacts with lipoteichoic acid on the surface of Streptococcus sanguis cells. Archives of Oral Biology 27, 261268.

Holtje, J. V. \& Tomasz, A. (1975). Biological effects of lipoteichoic acids. Journal of Bacteriology 124, 1023-1027.

Hughes, A. H., HaNCoCK, I. C. \& Baddiley, J. (1973). The function of teichoic acids in cation control in bacterial membranes. Biochemical Journal 132, 8393.

Jones, A. H., Marrouquin, R. \& Birdsell, D. C. (1983). Sialic acid in Actinomyces viscosus strain T14V and T14AV. (Abstract 65). Journal of Dental Research 62, 657.

Koga, T., OKahashi, N., Yamamoto, T., Mizuno, J., Inoue, M. \& Hamada, S. (1983). Purification and immunochemical characterization of Streptococcus sanguis ATCC 10557 serotype II carbohydrate antigen. Infection and Immunity 42, 696-701.

LAMbert, M. A. \& Moss, C. W. (1976). Cellular fatty acid composition of Streptococcus mutans and related streptococci. Journal of Dental Research 55, A96A97.

LAmbert, P. A., Hancock, I. C. \& Baddiley, J. (1977). Occurrence and function of membrane teichoic acids. Biochimica et biophysica acta 472, 112.

LOWRY, O. H., ROBERTS, N. R., LeINER, K. Y., WU, M.-L. \& FARR, A. L. (1954). The quantitative histochemistry of brain. 1. Chemical methods. Journal of Biological Chemistry 207, 1-17.

MCCARTY, M. (1959). The occurrence of polyglycerophosphate as an antigenic component of various gram-positive bacterial species. Journal of Experimental Medicine 109, 361-378.

Mejbaum, W. (1939). Über die Bestimmung kleiner Pentosemengen, insbesondere in Derivaten der Adenylsäure. Zeitschrift für physiologische Chemie 258, $117-120$.

Mizuno, J., Toril, M., Yamamoto, T. \& Hamada, S. (1983). Detection of amphipathic antigen unique to biotype B Streptococcus sanguis. FEMS Microbiology Letters 16, 209-212.

MoskowITZ, M. (1966). Separation and properties of a red cell sensitizing substance from streptococci. Journal of Bacteriology 91, 2200-2204.

Niedermeier, W. (1971). Gas chromatography of neutral and amino sugars in glycoproteins. Analytical Biochemistry 40, 465-475.

OFEK, I., BEACHEY, E. H., JEFFERSON, W. \& CAMPBELL, G. C. (1975). Cell membrane-binding properties of group A streptococcal lipoteichoic acid. Journal of Experimental Medicine 141, 990-1003.

OWEN, P. \& SAlton, M. R. J. (1975). A succinylated mannan in the membrane system of Micrococcus lysodeikticus. Biochemical and Biophysical Research Communications 63, 875-880.

Pless, D. D., Schmit, A. S. \& Lennarz, W. J. (1975). The characterization of mannan of Micrococcus lysodeikticus as an acidic lipopolysaccharide. Journal of Biological Chemistry 250, 1319-1327.

Powell, D. A., Duckworth, M. \& Baddiley, J. (1975). A membrane-associated lipomannan in micrococci. Biochemical Journal 151, 387-397.

Rosan, B., Lai, C. H. \& Listgarten, M. A. (1976). Streptococcus sanguis: a model in the application in immunochemical analysis for the in situ localization of bacteria in dental plaque. Journal of Dental Research 55, A124-A141.

Rosan, B. (1978). Absence of glycerol teichoic acids in certain oral streptococci. Science 201, 918-920.

RudczYNSKI, A. B. \& JACKSON, R. W. (1978). The properties of a lipoteichoic acid antigen from Streptococcus pyogenes. Immunochemistry 15, 83-91.

SALToN, M. R. J. (1983). From walls to membranes. Journal of General Microbiology 129, 2685-2702.

Sawardeker, J. S., Sloneker, J. H. \& Jeanes, A. (1965). Quantitative determination of monosaccharides as their alditol acetates by gas liquid chromatography. Analytical Chemistry 37, 1602-1604.

Scott, T. A. \& Melvin, E. H. (1953). Determination of dextran with anthrone. Analytical Chemistry 25, 1656-1661. 
SNyder, F. \& STEPhENS, N. (1959). A simplified spectrophotometric determination of ester group in lipids. Biochimica et biophysica acta 34, 244-245.

Sweeley, C. C., Bentley, R., Makita, M. \& Wells, W. W. (1963). Gas-liquid chromatography of trimethylsilyl derivatives of sugars and related substances. Journal of the American Chemical Society 85, 2497-2507.

Tomasz, A. (1974). The role of autolysins in cell death. Annals of the New York Academy of Sciences 235, 439-448.
WICKEN, A. J. \& KNox, K. W. (1980). Bacterial cell surface amphiphiles. Biochimica et biophysica acta 604, 1-26.

WICKEN, A. J., Broady, K. W., Evans, J. D. \& KNoX, K. W. (1978). New cellular and extracellular amphipathic antigen from Actinomyces viscosus NY1. Infection and Immunity 22, 615-616.

White, J. C. \& Niven, C. F., JR. (1946). Streptococcus s.b.e.: Streptococcus associated with subacute bacterial endocarditis. Journal of Bacteriology 51, 717722. 